OPEN ACCESS

Edited by:

Reinhild Klein,

University of Tübingen, Germany

Reviewed by:

Hongliang Zhang,

National Natural Science Foundation

of China, China

Hiu Yi Wong,

Hong Kong University of Science and

Technology, Hong Kong

*Correspondence:

Seyed Reza Mohebbi

sr.mohebbi@sbmu.ac.ir

Specialty section:

This article was submitted to

Multiple Sclerosis

and Neuroimmunology,

a section of the journal

Frontiers in Immunology

Received: 08 March 2021

Accepted: 21 April 2021

Published: 10 May 2021

Citation:

Shoraka S, Ferreira MLB, Mohebbi SR and Ghaemi A (2021) SARS-CoV-2

Infection and Guillain-Barré

Syndrome: A Review on Potential

Pathogenic Mechanisms.

Front. Immunol. 12:674922.

doi: 10.3389/fimmu.2021.674922

\section{SARS-CoV-2 Infection and Guillain-Barré Syndrome: A Review on Potential Pathogenic Mechanisms}

\author{
Shahrzad Shoraka ${ }^{1,2}$, Maria Lucia Brito Ferreira ${ }^{3}$, Seyed Reza Mohebbi ${ }^{\text {* }}$ \\ and Amir Ghaemi ${ }^{5}$
}

${ }^{1}$ Basic and Molecular Epidemiology of Gastrointestinal Disorders Research Center, Research Institute for Gastroenterology and Liver Diseases, Shahid Beheshti University of Medical Sciences, Tehran, Iran, ${ }^{2}$ Department of Microbiology and Microbial Biotechnology, Faculty of Life Sciences and Biotechnology, Shahid Beheshti University, Tehran, Iran, ${ }^{3}$ Department of Neurology, Hospital da Restauração, Recife, Brazil, ${ }^{4}$ Gastroenterology and Liver Diseases Research Center, Research Institute for Gastroenterology and Liver Diseases, Shahid Beheshti University of Medical Sciences, Tehran, Iran, ${ }^{5}$ Department of Virology, Pasteur Institute of Iran, Tehran, Iran

Since December 2019, the world has been facing an outbreak of a new disease called coronavirus disease 2019 (COVID-19). The COVID-19 pandemic is caused by a novel beta-coronavirus named severe acute respiratory syndrome coronavirus 2 (SARSCoV-2). The SARS-CoV-2 infection mainly affects the respiratory system. Recently, there have been some reports of extra-respiratory symptoms such as neurological manifestations in COVID-19. According to the increasing reports of Guillain-Barré syndrome following COVID-19, we mainly focused on SARS-CoV-2 infection and Guillain-Barré syndrome in this review. We tried to explain the possibility of a relationship between SARS-CoV-2 infection and Guillain-Barré syndrome and potential pathogenic mechanisms based on current and past knowledge.

Keywords: Coronavirus, COVID-19, SARS-CoV-2, Neurological manifestations, Guillain-Barré syndrome

\section{INTRODUCTION}

Over the past two decades, coronaviruses have caused three epidemic diseases named the severe acute respiratory syndrome (SARS), the Middle East respiratory syndrome (MERS), and coronavirus disease 2019 (COVID-19) (1). All these three diseases are caused by coronaviruses belonging to the beta genus $(2,3)$. Infections caused by these beta-coronaviruses show a variable range of clinical manifestations, from being asymptomatic to severe disease and death (4). Although pulmonary symptoms are considered the main clinical manifestation, neurological complications associated with these three respiratory coronaviruses have also been reported $(2,5)$.

In this review, we mainly focused on SARS-CoV-2 infection and Guillain-Barre syndrome and tried to explain the potential pathogenic mechanisms based on current and past knowledge. 


\section{VIROLOGY OF SARS-COV-2}

The coronavirus family consists of enveloped viruses with a positive single-stranded large RNA genome (6-8). Coronaviruses cause a wide variety of diseases in humans and some animals (9). Some of them have highly host-specific, while others are found on a range of hosts (10). According to genetic and serological properties, these viruses are divided into four subfamilies: $\alpha, \beta$, $\gamma$, and $\delta$, while the beta genus is also divided into four lineages of $A$, $\mathrm{B}, \mathrm{C}$, and $\mathrm{D}$. Human coronavirus $(\mathrm{HCoV})$ infections are caused only by alpha and beta genera $(11,12)$. Evidence indicated that the beta genus have more severe symptoms and complications compared to other genus (2). Besides, $\mathrm{HCoVs}$ are classified as zoonotic pathogens (13). Although these viruses cause respiratory infections in humans, their ability to affect other host organs such as heart, liver, gastrointestinal tract, kidney, Central and Peripheral Nervous System makes them complex pathogens $(2,5,14-17)$.

In December 2019, the emerging virus causing COVID-19 was added to the coronavirus family. The virus, called SARS$\mathrm{CoV}-2$ belongs to the beta group, same as SARS-CoV and MERS-CoV, but to the lineage B (3). Analyses showed the SARS-CoV- 2 is about $80 \%$ similar to the SARS-CoV. Both of these viruses enter the host cell by binding its surface spike protein to the host angiotensin converting enzyme-2 receptor (ACE-2). However, the binding affinity of the SARS-CoV-2 spike protein to the ACE-2 receptor is higher than that seen in SARS$\mathrm{CoV}$. Also it has recently been shown that SARS-CoV-2 may utilize basigin (BSG; CD147) and neuropilin-1 (NRP1) as binding receptors (18). Compared to SARS-CoV and MERS$\mathrm{CoV}$, the SARS-CoV-2 has higher transmissibility and pathogenicity $(2,3,19-22)$.

During the current pandemic, most patients with COVID-19 show respiratory symptoms such as dry cough and shortness of breath. SARS-CoV-2 infection has clinical manifestations similar to those reported for SARS and MERS. Therefore, these three viruses are mainly known as respiratory pathogens. However, they could contribute to symptoms and complications related to other organs, especially in severe cases $(2,5,23,24)$. Gastrointestinal, cardiac, hepatic, kidney, ocular, cutaneous, and haematological, symptoms are the main extra-respiratory manifestations of patients with COVID-19 (8, 25-27). Recently, neurological symptoms were reported in some COVID-19 cases, raising concerns about the potential of the SARS-CoV-2 to invade nerves and lead to neurological complications, both in

\footnotetext{
Abbreviations: COVID-19, coronavirus disease 2019; SARS-CoV-2, severe acute respiratory syndrome coronavirus 2 , SARS, severe acute respiratory syndrome; MERS, Middle East respiratory syndrome; RNA, ribonucleic acid; HCoV, Human coronavirus; ACE-2, angiotensin converting enzyme-2 receptor; BSG, basigin; NRP1, neuropilin-1; CNS, central nervous system; PNS, peripheral nervous system; AFP, acute flaccid paralysis; MS, multiple sclerosis; ADEM, acute demyelinating encephalomyelitis; GBS, Guillain-Barré syndrome; RT-PCR, reverse transcriptase PCR; PCR, polymerase chain reaction; CSF, cerebrospinal fluid; BBE, Bickerstaff's encephalitis; CoVs, coronaviruses; IL, interleukin; TNF- $\alpha$, tumor necrosis factor-alpha; CMV, cytomegalovirus; EBV, Epstein-Barr virus; arboviruses, arthropod-borne viruses; ZIKV, zika virus; HSP, heat shock proteins; IFN- $\gamma$, interferon- $\gamma$; MND, motor neuron diseases.
}

the acute and chronic phases. The term "neuro-COVID" is used to describe these complications $(28,29)$.

\section{NEUROVIRULENCE OF HUMAN CORONAVIRUSES}

The prevalence of neuro-COVID has been reported to vary between studies. Although the prevalence rate of neurological symptoms is estimated to be around 3.5 to $84 \%$ among COVID-19 patients, in most cases the SARS-CoV-2 RNA was not detected in the cerebrospinal fluid (CSF) $(28,30,31)$. Among 58 patients with COVID-19 and neurological symptoms, the SARS-CoV-2 RNA was detected in CSF of 2 patients (3.4\%). One patient with refractory headache and another with ADEM four days after the onset of COVID-19 symptoms (32). Also Domingues et al. detected SARSCoV-2 in CSF using by RT-PCR and confirmed with deep sequenced. There was a 99.74 to $100 \%$ similarity between the patient virus to the worldwide sequences (33). On the other hand, organoids and in vivo studies in human ACE2 transgenic mice have demonstrated that the SARS-CoV-2 could infect neurons and contribute to cell death and neural damage. However, CSF and autopsy findings do not provide consistent support for direct CNS invasion. So SARS-CoV-2 related neurological symptoms may be the consequences of different mechanisms $(18,29,34)$.

Given that coronaviruses could lead to short- or long-term neurological disorders, there was a hypothesis that these viruses may have neurovirulence because of the neurotropism and neuroinvasion of human coronaviruses (35-39). Since 2000, Arbour et al. found $\mathrm{HCoV}$ RNA in brain samples outside blood vessels, and affirmed the consistence of neuroinvasion by these respiratory pathogens in humans but considered the need of further studies to distinguish between opportunistic and disease-associated viral presence (40).

It seems that coronaviruses could be responsible for direct and indirect neurological symptoms and complications with central nervous system (CNS) (including headache, epileptic seizure, impaired consciousness and dizziness) and peripheral nervous system (PNS) manifestations (such as Guillain-Barré syndrome, anosmia and neuralgia) (41), divided as parainfectious and post-infectious (5, 8, 23, 34, 42-45) (see Figure 1).

During the SARS-CoV and MERS-CoV outbreak, some neurological symptoms were among their other extra-pulmonary complications (Table 1). At the present SARS-Cov-2 outbreak, there have been increasing reports of clinical neurological disorders such as acute encephalomyelitis, acute flaccid paralysis (AFP), multiple sclerosis (MS), acute demyelinating encephalomyelitis (ADEM), and Guillain-Barré syndrome (GBS) as possible complications, supporting its neuroinvasion nature $(12,40,51-$ 53). Among them, Guillain-Barre Syndrome is the most frequent.

\section{GUILLAIN-BARRÉ SYNDROME AND SARS-COV-2 INFECTION}

Guillain-Barre syndrome is an acute acquired autoimmune disorder of the peripheral nerves that often occurs after 


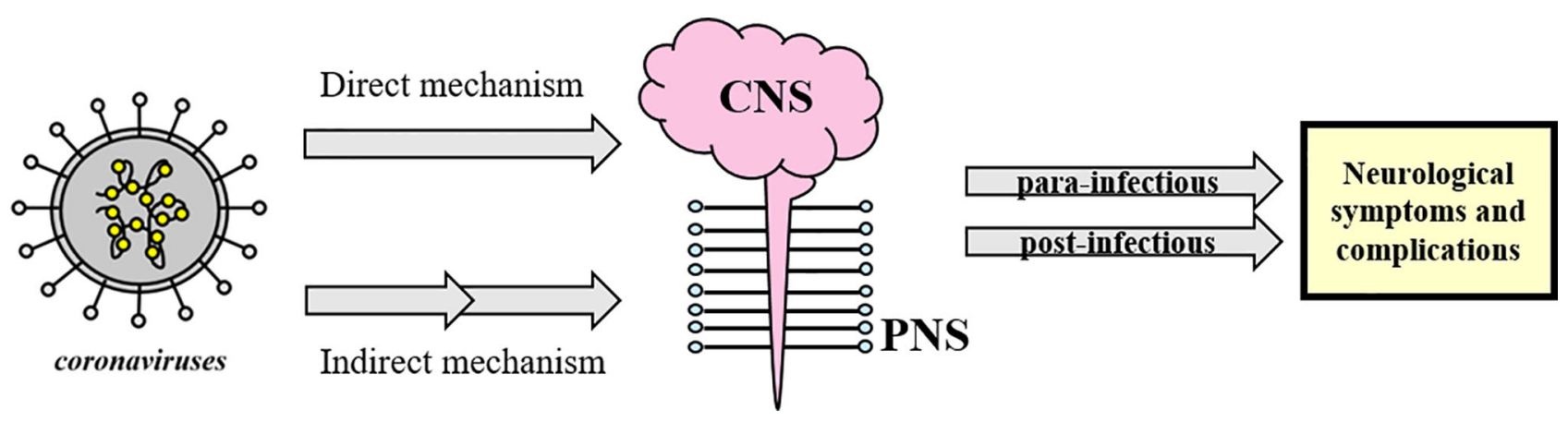

FIGURE 1 | Schematic classification of neurological complications associated with coronavirus infections. Coronaviruses could directly or indirectly affect the CNS and/or PNS and lead to post- or para-infectious neurological complications. The concept appears to be generalizable to SARS-CoV-2 as well.

TABLE 1 | Neurological symptoms attributable to SARS-CoV-2 published in 2020 and 2021.

Authors

Attributable neurological symptoms

Mao et al. (46) Neurological manifestations involving CNS and PNS present in 78 of 214 (36.4\%) patients. The neurological symptoms were more common (45.5\%) in those with more severe infection

Karadas et al. Cerebrovascular disorders, epileptic seizures, impaired consciousness; dizziness, olfactory and taste disorders were neurological symptoms. These

(47) symptoms were present in 83 of the 239 (34.7\%) patients and headache was the most common (27.6\%)

Rifino et al. Cerebrovascular disease, peripheral nervous system disease, altered mental status, and miscellaneous disorders present in 137 of 1,760

(48) COVID-19 patients

Chen et al. (49) Consciousness disorders were present on admission in $22 \%$ of patients who died compared with $1 \%$ who recovered

Chuang et al. Out of 282 patients with neurological problems, 56 had a COVID-19 positive test. Of these, 23 patients had no symptoms of COVID-19 while 33 had. (50) In both groups, weakness of consciousness was the most common primary neurological symptom

infection (54). In fact, GBS is symmetrical ascending paralysis, often caused by respiratory or gastrointestinal infections from a virus or bacteria (4). Many bacteria and viruses have been considered as possible trigger of $\operatorname{GBS}(55,56)$. Before the recent pandemic, few cases of coronavirus associated to GBS were reported, but a systematic review pointed a significant increasing number of patients with GBS after the COVID-19 pandemic, with higher prevalence among older patients (mean age of 60 years) than with younger ones (mean age of 40 years) (57) (Table 2).

GBS associated to SARS-CoV-2 infection may follow the typical post-infectious pattern, with report indicating that it is also possible in children. GBS has also been reported as part of the "long COVID-19 syndrome" $(69,73)$. Nevertheless, there are also reports that GBS is a para-infectious paralysis associated with a viral infection (74). Almost all reported cases have acute onset within a few days of onset of viral infection (75) (see Figure 2).

\section{Possible Mechanisms of Guillain-Barré Syndrome Involving Virus and Bacteria}

Molecular mimicry between microbial and neural antigens is a major driving force in this disorder. The interaction between microbial agents and the host that dictates the immune response to the unwanted auto reactivity is not well understood yet. On the other hand, most people (>99\%) who are exposed to immune stimulus, as a result of GBS-associated infection do not develop unwanted autoimmunity. It seems that genetics and environmental factors affect the susceptibility of individual to this disease $(56,76,77)$.

The association of various microorganisms with GuillainBarré syndrome has been reported such as Campylobacter jejuni (C. jejuni), Mycoplasma pneumoniae, Haemophilus influenza, Cytomegalovirus (CMV), Epstein-Barr virus (EBV), influenza A, varicella-zoster, hepatitis (A, B and E), Zika and Chikungunya viruses (78-91). C. jejuni has been identified as the most common pathogen causing this disorder $(91,92)$.

In 2001, Yuki showed that the core lipo-oligosaccharides of the Campylobacter jejuni strains associated with GBS have structural similarities to various gangliosides in peripheral nerve membranes, suggesting that molecular mimicry of gangliosides may contribute to GBS (93). Molecular mimicry of gangliosides in C. jejuni results in the production of anti-ganglioside antibodies that bind to gangliosides in the axonal membrane at the Ranvier node. Activation of complement leads to disruption of voltage-gated sodium channels, disruption of nodal structure, and formation of the membrane attack complex that leads to calcium influx. Eventually, these changes cause axonal damage and attract macrophages, which could then migrate between axon and myelin (80, 94). Guillain-Barré-associated viral infections show similar mechanisms to bacterial GBS. However, due to the wide range of viral antigens that may be associated with GBS, the pathophysiology, the clinical course, and outcomes may vary (78). 
TABLE 2 | Cases of GBS associated to coronavirus.

\begin{tabular}{|c|c|c|}
\hline Authors & Year & Attributable neurological symptoms \\
\hline \multicolumn{3}{|c|}{ Before the recent pandemic } \\
\hline Kim et al. (58) & 2017 & $\begin{array}{l}\text { After a severe infection, 55-year-old man with a positive test for MERS-CoV showed hypersomnolence, ophthalmoplegia and relative } \\
\text { symmetric motor weakness in all four limbs. Given the infection history the GBS variant was considered a possible diagnosis. The patient had } \\
\text { progressive symmetric external ophthalmoplegia, ataxia, and impaired consciousness with limb weakness, and the diagnosis of Bickerstaff's } \\
\text { encephalitis (BBE) overlap with GBS was suggested. }\end{array}$ \\
\hline $\begin{array}{l}\text { Sharma et al. } \\
\text { (53) }\end{array}$ & 2019 & $\begin{array}{l}\text { A 5-year-old boy with a 7-day history of bilateral lower limb pain, irritability, difficulty walking, and loss of balance, } 4 \text { days after left facial droop } \\
\text { and inability to close the left eye as well as fever and a stuffy nose two weeks earlier. Diagnosis of GBS was supported by areflexia and } \\
\text { albuminocytologic dissociation. The positivity of multiplex PCR for HCoV-OC43 indicated that coronavirus infection may have caused atypical } \\
\text { GBS }\end{array}$ \\
\hline \multicolumn{3}{|c|}{ During the recent pandemic, GBS post a SARS-CoV-2 } \\
\hline Coen et al. (59) & 2020 & $\begin{array}{l}\text { A 70-year-old man suffered from myalgia, fatigue, and dry cough and } 10 \text { days after he was hospitalized for paraparesis, distal allodynia, } \\
\text { voiding problem, and constipation. Since his SARS-CoV-2 test was positive before the first signs of polyneuropathy, it supports a post- } \\
\text { infectious GBS phenotype }\end{array}$ \\
\hline $\begin{array}{l}\text { Camdessanche } \\
\text { et al. (60) }\end{array}$ & 2020 & $\begin{array}{l}\text { A 64-year-old man had fever and cough after a lesion in his shoulder and evolved with moderate dyspnea. His nasopharyngeal swab was } \\
\text { positive for SARS-CoV-2. After five days without fever, he complained of paresthesia in feet and hands and within three days he had a flaccid } \\
\text { severe tetraparesia. Five days after the electrodiagnosis of GBS was confirmed. }\end{array}$ \\
\hline $\begin{array}{l}\text { Sedaghat and } \\
\text { Karimi (61) }\end{array}$ & 2020 & $\begin{array}{l}\text { A 65-year-old man had a positive SARS-CoV2 test. Twelve days after he presented to the emergency room symptoms of acute progressive } \\
\text { symmetric ascending quadriparesis. Neurological and laboratory findings supported the diagnosis of GBS }\end{array}$ \\
\hline $\begin{array}{l}\text { Padroni et al. } \\
\text { (62) }\end{array}$ & 2020 & $\begin{array}{l}\text { A 70-year-old woman had fever and cough and a positive result of the nasopharyngeal swab for SARS-CoV-2. After few weeks she } \\
\text { presented GBS symptoms. Microbiological tests on her CSF were negative }\end{array}$ \\
\hline Rifino et al. (48) & 2020 & 17 out of 31 COVID-19 patients with peripheral neuropathies, had GBS \\
\hline $\begin{array}{l}\text { Khalifa et al. } \\
\text { (63) }\end{array}$ & 2020 & An 11-year-old boy had a diagnosis of GBS associated with SARS-CoV-2 infection \\
\hline $\begin{array}{l}\text { Alberti et al. } \\
\text { (64) }\end{array}$ & 2020 & $\begin{array}{l}\text { A 71-year-old man had a mild fever for a few days. One week after he was referred to the emergency department with paresthesia at the } \\
\text { limb and flaccid tetraparesis. Nasopharyngeal swab was positive, but CSF was negative for SARS-CoV-2 }\end{array}$ \\
\hline $\begin{array}{l}\text { Toscano et al. } \\
\text { (65) }\end{array}$ & 2020 & $\begin{array}{l}\text { Of five patients, who developed GBS after the onset of COVID-19 symptoms, four had a positive nasopharyngeal swab for SARS-CoV-2 at } \\
\text { the time of neurologic symptoms and a negative CSF. The interval between the onset of viral infection and the first symptoms of GBS was } \\
\text { five to ten days }\end{array}$ \\
\hline $\begin{array}{l}\text { Filosto et al. } \\
\text { (66) }\end{array}$ & 2020 & $\begin{array}{l}\text { Of } 34 \text { patients with GBS diagnosed during the outbreak of SARS-CoV-2 in } 12 \text { referral hospitals in seven cities in northern Italy, } 30 \text { patients } \\
(88.2 \%) \text { were diagnosed with confirmed SARS-CoV-2. The incidence of GBS in March and April } 2020 \text { in northern Italy has increased } 2.6 \text { fold } \\
\text { compared to same months of } 2019\end{array}$ \\
\hline $\begin{array}{l}\text { Dufour et al. } \\
\text { (67) }\end{array}$ & 2021 & A 36-year-old woman with progressive ascending weakness consistent with GBS. She had recovered from mild COVID-19 two weeks ago \\
\hline Tekin et al. (68) & 2021 & A 34-year-old woman who developed COVID-19 at 37th gestational week was diagnosed with GBS at postpartum \\
\hline $\begin{array}{l}\text { Raahimi et al. } \\
\text { (69) }\end{array}$ & 2021 & $\begin{array}{l}\text { A 46-year-old man was diagnosed with GBS } 53 \text { days after having COVID-19. This is a case report of delayed onset of GBS following the } \\
\text { SARS-CoV-2 infection }\end{array}$ \\
\hline \multicolumn{3}{|c|}{ During the recent pandemic, GBS para-infectious paralysis } \\
\hline Zhao et al. (70) & 2020 & $\begin{array}{l}\text { A } 61 \text {-year-old woman with acute weakness in both legs and a diagnosis of GBS. On the eighth day, the patient started having a dry cough } \\
\text { and fever. Then, the oropharyngeal swab test for SARS-CoV-2 was positive. }\end{array}$ \\
\hline $\begin{array}{l}\text { Ottaviani et al. } \\
\text { (71) }\end{array}$ & 2020 & $\begin{array}{l}\text { A 66-year-old woman who presented GBS neurological symptoms one week after the onset of respiratory symptoms while they progressed } \\
\text { simultaneously }\end{array}$ \\
\hline $\begin{array}{l}\text { Bastug et al. } \\
(72)\end{array}$ & 2021 & A 66-year-old man with GBS neurological findings occurred on the third day of the COVID-19 diagnosis \\
\hline
\end{tabular}

Studies have described the role of GM2 anti-glycoside antibodies in the pathogenesis of CMV-related GBS. The findings of these studies showed that anti-GM2 IgM antibodies are induced in acute cytomegalovirus infection through molecular mimicry between GM2 and the antigens induced by CMV infection $(77,93,95,96)$. For hepatitis A, B, C, or E, a definite homogeneous epitope with components of the peripheral nerve has not yet been described. However, in 2009, Loly et al. reported the presence of anti-ganglioside GM2 antibodies in hepatitis E virus-related GBS. They have declare a possible molecular mimicry of gangliosides (97).

Over the past decades, studies have demonstrated a possible link between the arthropod-borne viruses (arboviruses) including Zika and Chikungunya virus and the development of GBS (98-102). Shortly after the outbreak of ZIKV, in 2015, a cluster of cases with GBS was identified in Brazil (103). Also, a case-control study in France revealed that out of 42 patients diagnosed with Guillain-Barré syndrome, 41 (98\%) had anti-Zika virus IgM or IgG, and all (100\%) had neutralizing antibody against the Zika virus (104). The analysis of case series from seven countries showed that the changes in the reported incidence of Zika virus disease during 2015 and early 2016 were closely related to the change in the incidence of GuillainBarré syndrome (105).

In the case of GBS associated with the Zika virus, several antiganglioside antibodies also are indicated and may play a role in the mechanism of molecular mimicry $(104,106,107)$. In addition, there are other alternative mechanisms described for Zika-related GBS. It could be due to a direct viral neuropathic effect, and cross-reactive antibodies formed during previous infections with a detrimental effect on nerve function. The underlying mechanisms of para-infectious pathogenesis have not yet been identified. It has been suggested that specific Zika virus-peptides may not only cross-react but also induce a cellular 

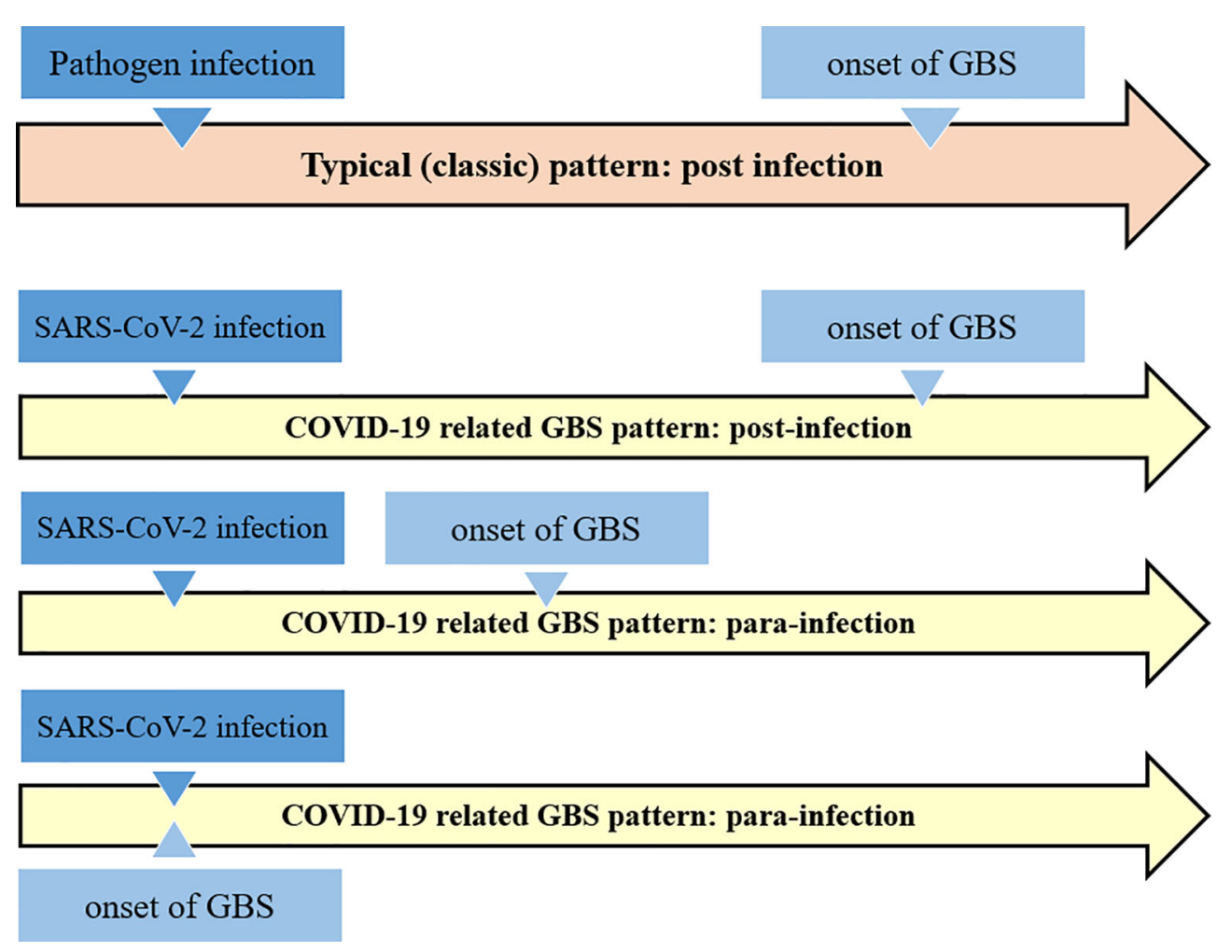

FIGURE 2 | Schematic comparison of the classical Guillain-Barré syndrome pattern with the COVID-19 related GBS. It appears that COVID-19 related GBS follow the both post- and para-infections patterns.

immune response via antigen-presenting cell activation of T-lymphocytes (104, 106, 108, 109).

During the recent pandemic, there is also growing evidence that SARS-CoV-2 infection is associated with immune-mediated neurological complications, for example, in the form of GBS (65, 110). The exact pathogenesis of COVID-19-related neurological damage is still largely unknown. Considering that previous viral outbreaks, molecular mimicry between SARS-CoV-2 and various human organs and tissues have been hypothesized as a potential trigger of multi-organ autoimmunity in COVID-19 (104, 111114). Moreover, failure to detect the SARS-CoV-2 in most of the CSF patient samples supports an immune mechanism rather than direct invasion (18).

In a recent study by Lucchese and Flöel, sequence analysis of the 41 human proteins associated with acute and chronic immune-mediated neuropathies revealed that SARS-CoV-2 contained two immunologically-related hexapeptides (KDKKKK in nucleocapsid and EIPKEE in Orflab) with the human heat shock proteins 90 (HSP90B and HSP90B2) and 60 (HSP60), respectively (113). These authors hypothesized that SARS-CoV2 infection may trigger an adaptive immune response in which $\mathrm{T}$ cell-B cell interactions result in the production specific antibodies similar to ganglioside-peptide sequences or structure, resulting in loss of self-tolerance (113). The gangliosides located on the membranes of neurons and the Schwann-cells, which form the myelin sheath, act as receptors for antiganglioside antibodies, promoting neutralization of neurons complement inhibitory activity, which turn them into targets for autoimmune-mediated destruction of myelin sheaths or axons (113).

About 50 to $85 \%$ of previously reported cases with GBS or its variants have anti-ganglioside antibodies in their serum. However, there are limited data on the presence of antiganglioside antibodies in the patients with COVID-19 related GBS. Studies have not reported increase in the serum titers of anti-ganglioside antibodies in GBS patients with COVID-19. Recently, Dufour et al. reported first case with COVID-19 related GBS with positive GM1 antibody $(67,75)$. Therefore, further studies are necessary to confirm the presence of antiganglioside antibodies in COVID-19 related GBS.

This molecular mimicry has also been shown in the implication of HSPs in some immune-mediated clinical conditions (115). A 2015 study by Loshaj-Shala et al. reported a high homology between $C$. jejuni DnaK and GroEL with the human peripheral nerve HSP70 and HSP60, respectively. These results strongly support the potential role of chaperone molecules in the progression of the autoimmune response related to GBS (92). Also an etiological relationship between some neurological diseases and autoantibodies against HSP family proteins has sometimes been described $(116,117)$. It is noteworthy that autoantibodies targeting different families of HSPs were increased in serum and CSF of patients with GBS compared to healthy controls $(118,119)$. In a study, Yonekura et al. demonstrated that IgG and IgM antibody titers against several HSPs (including 
HSP60) were significantly higher in the CSF of patients with GBS in the acute phase than patients with motor neuron diseases (MND) (120). The sharing of peptide motifs with immunologic potential between SARS-CoV-2 and HSPs strongly supports immunemediated neuronal damage (121).

The role of neuroinflammation and the effect of cytokine storm caused by SARS-CoV-2 infection on the nervous system have been discussed. In COVID-19 patients, an increase has been observed in cytokines such as interleukin-1 $\beta$ (IL-1 $1 \beta$ ), IL-6, IL-17, TNF- $\alpha$ and interferon- $\gamma$ (IFN- $\gamma$ ), along with other chemokines. Because many of the same cytokines have been implicated in the pathogenesis of typical GBS, the cytokine storm in COVID-19 may play a pivotal role in the simultaneous development and progression of GBS (75). Zhang et al. in 2013 reported elevated serum TNF- $\alpha$ levels during acute phase of GBS and it was associated with clinical severity of the disease (122). CSF levels of IFN- $\gamma$, IL-4, IL-17, and IL-22 are increased in GBS, and IL-17 and IL-22 levels are associated with disease severity (123-125). However, the role of cytokines in COVID-19 related GBS needs further investigation $(126,127)$.

Here, we describe the possible mechanisms that may be involved in the development of Guillain-Barre syndrome following the SARS-CoV-2 infection. Further studies are needed to better understand the possible mechanism of this relation. To confirm the exact pathogenic mechanism, identification of $\mathrm{T}$ cell responses, or particular antibodies to the target autoantigen; recognition of structural homology between the infectious agent and the target autoantigen and, finally, reproduction of the disease following immunization with the infectious agent in an animal model should be considered (128).

\section{CONCLUSION, FUTURE DIRECTIONS, AND NEW INSIGHTS}

During the recent pandemic, many cases of Guillain-Barre syndrome have been reported to be associated with COVID19. In this review article, we have discussed the possibility of a relationship between SARS-CoV-2 infection and Guillain-Barré syndrome and potential pathogenic mechanisms based on current and past knowledge. It is noteworthy that during the recent pandemic, there have been several case reports of the

\section{REFERENCES}

1. De Wit E, Van Doremalen N, Falzarano D, Munster VJ. SARS and MERS: Recent Insights Into Emerging Coronaviruses. Nat Rev Microbiol (2016) 14:523-34. doi: 10.1038/nrmicro.2016.81

2. Harb JG, Noureldine HA, Chedid G, Eldine MN, Abdallah DA, Chedid NF, et al. Sars, MERS and COVID-19: Clinical Manifestations and OrganSystem Complications: A Mini Review. Pathog Dis (2020) 78:1-7. doi: 10.1093/femspd/ftaa033

3. Wang L, Wang Y, Ye D, Liu Q. Review of the 2019 Novel Coronavirus (SARS-CoV-2) Based on Current Evidence. Int J Antimicrob Agents (2020) 55:105948. doi: 10.1016/j.ijantimicag.2020.105948

4. Bridwell R, Long B, Gottlieb M. Neurologic Complications of COVID-19. Am J Emerg Med (2020) 38:1549.e3-.e7. doi: 10.1016/j.ajem.2020.05.024 para-infectious pattern of GBS according to SARS-CoV-2 infection. On the other hand, GBS may be part of the "long COVID-19 syndrome". Therefore, Guillain-Barre syndrome associated with SARS-CoV-2 in addition to the classic postinfectious profile might follow the pattern of a para-infectious as reported in Guillain-Barre syndrome associated with the Zika virus. Identifying and linking para- and post-infectious neurological diseases such as GBS to a pandemic is confusing. Besides, accurate and timely diagnosis is critical. Therefore, considering that there may be a link between SARS-CoV-2 infection and GBS is helpful in rapid diagnosis of patients. We have also highlighted that the possible role of indirect immunemediated mechanisms, such as molecular mimicry and neuroinflammation, is more than direct viral invasion in the development of COVID-19 related GBS. Also further molecular studies are needs to investigate the exact mechanism that leads to the GBS following the SARS-CoV-2 infection.

In conclusion, although many studies support the link between SARS-CoV-2 infection and GBS, more evidence is needed to confirm their relationship and describe its exact mechanism. Epidemiological evidence associated with the suspected infectious agent and GBS should be considered to approve the association between COVID-19 and GBS. However, based on recent reports, we suggest that all newly diagnosed Guillain-Barré cases should be tested for SARS-CoV-2 infection in the current pandemic, even if they have no respiratory complaints.

\section{AUTHOR CONTRIBUTIONS}

SRM: article decision, planning, and writing. SHSH: literature search and reviewing and article writing. MLBF: manuscript revision on Neurology. AGH: article reviewing. All authors contributed to the article and approved the submitted version.

\section{ACKNOWLEDGMENTS}

The authors would like to acknowledge the support from the Research Institute for Gastroenterology and Liver Diseases, Shahid Beheshti University of Medical Sciences.

5. Kwong KCNK, Mehta PR, Shukla G, Mehta AR. COVID-19, SARS and MERS: A Neurological Perspective. J Clin Neurosci (2020) 77:13-6. doi: 10.1016/j.jocn.2020.04.124

6. He F, Deng Y, Li W. Coronavirus Disease 2019: What We Know? J Med Virol (2020) 92:719-25. doi: 10.1002/jmv.25766

7. Sahin AR. 2019 Novel Coronavirus (COVID-19) Outbreak: A Review of the Current Literature. Eurasian J Med Oncol (2020) 4:1-7. doi: 10.14744/ ejmo.2020.12220

8. Nordvig AS, Rimmer KT, Willey JZ, Thakur KT, Boehme AK, Vargas WS, et al. Potential Neurological Manifestations of COVID-19. Neurol: Clin Pract (2020) 11(2):e135-46. doi: 10.1212/CPJ.0000000000000897

9. Fehr AR, Perlman S. Coronaviruses: An Overview of Their Replication and Pathogenesis. Coronaviruses: Methods Protocols: Springer (2015) 1282. doi: 10.1007/978-1-4939-2438-7_1 
10. Wassenaar TM, Zou Y. 2019_nCoV/SARS-CoV-2: Rapid Classification of Betacoronaviruses and Identification of Traditional Chinese Medicine as Potential Origin of Zoonotic Coronaviruses. Lett Appl Microbiol (2020) 70:342-8. doi: 10.1111/lam.13285

11. Li X, Geng M, Peng Y, Meng L, Lu S. Molecular Immune Pathogenesis and Diagnosis of COVID-19. J Pharm Anal (2020) 10:102-8. doi: 10.1016/ j.jpha.2020.03.001

12. Paules CI, Marston H, Fauc AS. Coronavirus Infections-More Than Just the Common Cold. J Am Med Assoc (2020) 323:707-8. doi: 10.1001/jama.2020.0757

13. Forni D, Cagliani R, Clerici M, Sironi M. Molecular Evolution of Human Coronavirus Genomes. Trends Microbiol (2017) 25:35-48. doi: 10.1016/ j.tim.2016.09.001

14. Phan T. Novel Coronavirus: From Discovery to Clinical Diagnostics. Infect Genet Evol (2020) 79:104211. doi: 10.1016/j.meegid.2020.104211

15. Alsaied T, Aboulhosn JA, Cotts TB, Daniels CJ, Etheridge SP, Feltes TF, et al. Coronavirus Disease 2019 (COVID-19) Pandemic Implications in Pediatric and Adult Congenital Heart Disease. J Am Heart Assoc (2020) 9:e017224. doi: 10.1161/JAHA.120.017224

16. Henry BM, Lippi G. Chronic Kidney Disease is Associated With Severe Coronavirus Disease 2019 (COVID-19) Infection. Int Urol Nephrol (2020) 52:1193-4. doi: 10.1007/s11255-020-02451-9

17. Xu L, Liu J, Lu M, Yang D, Zheng X. Liver Injury During Highly Pathogenic Human Coronavirus Infections. Liver Int (2020) 40:998-1004. doi: 10.1111/ liv. 14435

18. Iadecola C, Anrather J, Kamel H. Effects of COVID-19 on the Nervous System. Cell (2020) 183:16-27.el. doi: 10.1016/j.cell.2020.08.028

19. Wu F, Zhao S, Yu B, Chen YM, Wang W, Song ZG, et al. A New Coronavirus Associated With Human Respiratory Disease in China. Nature (2020) 579:265-9. doi: 10.1038/s41586-020-2008-3

20. Zhou P, Yang XL, Wang XG, Hu B, Zhang L, Zhang W, et al. A Pneumonia Outbreak Associated With a New Coronavirus of Probable Bat Origin. Nature (2020) 579:270-3. doi: 10.1038/s41586-020-2012-7

21. Das G, Mukherjee N, Ghosh S. Neurological Insights of COVID-19 Pandemic. ACS Chem Neurosci (2020) 11:1206-9. doi: 10.1021/acschemneuro.0c00201

22. Wrapp D, Wang N, Corbett KS, Goldsmith JA, Hsieh CL, Abiona O, et al. Cryo-EM Structure of the 2019-nCoV Spike in the Prefusion Conformation. Science (2020) 367:1260-3. doi: 10.1126/science.abb2507

23. Huang C, Wang Y, Li X, Ren L, Zhao J, Hu Y, et al. Clinical Features of Patients Infected With 2019 Novel Coronavirus in Wuhan, China. Lancet (2020) 395:497-506. doi: 10.1016/S0140-6736(20)30183-5

24. Li YC, Bai WZ, Hashikawa T. The Neuroinvasive Potential of SARS-CoV2 may Play a Role in the Respiratory Failure of COVID-19 Patients. J Med Virol (2020) 92:552-5. doi: 10.1002/jmv.25728

25. Lai CC, Ko WC, Lee PI, Jean SS, Hsueh PR. Extra-Respiratory Manifestations of COVID-19. Int J Antimicrob Agents (2020) 56:106024. doi: 10.1016/j.ijantimicag.2020.106024

26. Long B, Brady WJ, Koyfman A, Gottlieb M. Cardiovascular Complications in COVID-19. AmJEmerg Med (2020) 38:1504-7. doi: 10.1016/j.ajem.2020.04.048

27. Pei G, Zhang Z, Peng J, Liu L, Zhang C, Yu C, et al. Renal Involvement and Early Prognosis in Patients With COVID-19 Pneumonia. J Am Soc Nephrol (2020) 31:1157-65. doi: 10.1681/ASN.2020030276

28. Heming M, Li X, Räuber S, Mausberg AK, Börsch A-L, Hartlehnert M, et al. Neurological Manifestations of COVID-19 Feature T Cell Exhaustion and Dedifferentiated Monocytes in Cerebrospinal Fluid. Immunity (2021) 54 (1):164-75.e6. doi: 10.1016/j.immuni.2020.12.011

29. Cheng Q, Yang Y, Gao J. Infectivity of Human Coronavirus in the Brain. EBioMedicine (2020) 56:102799. doi: 10.1016/j.ebiom.2020.102799

30. Nersesjan V, Amiri M, Lebech A-M, Roed C, Mens H, Russell L, et al. Central and Peripheral Nervous System Complications of COVID-19: A Prospective Tertiary Center Cohort With 3-Month Follow-Up. J Neurol (2021), 1-19. doi: 10.1007/s00415-020-10380-x

31. Perrin P, Collongues N, Baloglu S, Bedo D, Bassand X, Lavaux T, et al. Cytokine Release Syndrome-Associated Encephalopathy in Patients With COVID-19. Eur J Neurol (2021) 28(1):248-58. doi: 10.1111/ene.14491

32. Espíndola OM, Brandão CO, Gomes YCP, Siqueira M, Soares CN, Lima MASD, et al. Cerebrospinal Fluid Findings in Neurological Diseases Associated With COVID-19 and Insights Into Mechanisms of Disease Development. Int $J$ Infect Dis (2021) 102:155-62. doi: 10.1016/j.ijid.2020.10.044
33. Domingues RB, Mendes-Correa MC, de Moura Leite FBV, Sabino EC, Salarini DZ, Claro I, et al. First Case of SARS-COV-2 Sequencing in Cerebrospinal Fluid of a Patient With Suspected Demyelinating Disease. J Neurol (2020) 267:3154-6. doi: 10.1007/s00415-020-09996-w

34. Lahiri D, Ardila A. COVID-19 Pandemic: A Neurological Perspective. Cureus (2020) 12:2-7. doi: 10.7759/cureus.7889

35. Desforges M, Le Coupanec A, Dubeau P, Bourgouin A, Lajoie L, Dubé M, et al. Human Coronaviruses and Other Respiratory Viruses: Underestimated Opportunistic Pathogens of the Central Nervous System? Viruses (2019) 12:1-28. doi: 10.3390/v12010014

36. Verstrepen K, Baisier L, De Cauwer H. Neurological Manifestations of COVID-19, SARS and MERS. Acta Neurol Belg (2020) 120:1051-60. doi: 10.1007/s13760-020-01412-4

37. Rodriguez-Morales AJ, Rodriguez-Morales AG, Méndez CA, HernándezBotero S. Tracing New Clinical Manifestations in Patients With COVID-19 in Chile and Its Potential Relationship With the SARS-CoV-2 Divergence. Curr Trop Med Rep (2020) 7:75-8. doi: 10.1007/s40475-020-00205-2

38. Desforges M, Coupanec AL, Brison É, Meessen-Pinard M, Talbot PJ. Neuroinvasive and Neurotropic Human Respiratory Coronaviruses: Potential Neurovirulent Agents in Humans. Adv Exp Med Biol (2014) 807:75-96. doi: 10.1007/978-81-322-1777-0_6

39. Desforges M, Le Coupanec A, Dubeau P, Bourgouin A, Lajoie L, Dubé M, et al. Human Coronaviruses and Other Respiratory Viruses: Underestimated Opportunistic Pathogens of the Central Nervous System? Viruses (2020) 12 (1):14. doi: $10.3390 / \mathrm{v} 12010014$

40. Arbour N, Day R, Newcombe J, Talbot PJ. Neuroinvasion by Human Respiratory Coronaviruses. J Virol (2000) 74:8913-21. doi: 10.1128/ JVI.74.19.8913-8921.2000

41. Liu JM, Tan BH, Wu S, Gui Y, Suo JL, Li YC. Evidence of Central Nervous System Infection and Neuroinvasive Routes, as Well as Neurological Involvement, in the Lethality of SARS-CoV-2 Infection. $J$ Med Virol (2021) 93(3):1304-13. doi: 10.1002/jmv.26570

42. Baig AM. Neurological Manifestations in COVID-19 Caused by SARS-CoV2. CNS Neurosci Ther (2020) 26:499-501. doi: 10.1111/cns.13372

43. Iroegbu JD, Ifenatuoha CW, Ijomone OM. Potential Neurological Impact of Coronaviruses: Implications for the Novel SARS-CoV-2. Neurol Sci (2020) 41:1329-37. doi: 10.1007/s10072-020-04469-4

44. Desforges M, Le Coupanec A, Stodola JK, Meessen-Pinard M, Talbot PJ. Human Coronaviruses: Viral and Cellular Factors Involved in Neuroinvasiveness and Neuropathogenesis. Virus Res (2014) 194:145-58. doi: 10.1016/j.virusres.2014.09.011

45. Goés A, Cardoso BB, Tavares F, Monte R, Melo RC, Araújo-Neto I, et al. COVID-19 and Nervous System: Under Estimated Clinical and Prognostic Aspects. Int J Neurol Neurotherapy (2020) 7:1-7. doi: 10.23937/2378-3001/ 1410100

46. Mao L, Jin H, Wang M, Hu Y, Chen S, He Q, et al. Neurologic Manifestations of Hospitalized Patients With Coronavirus Disease 2019 in Wuhan, China. JAMA Neurol (2020) 77:683-90. doi: 10.1001/jamaneurol.2020.1127

47. Karadaş Ö, Öztürk B, Sonkaya AR. A Prospective Clinical Study of Detailed Neurological Manifestations in Patients With COVID-19. Neurol Sci (2020) 41:1991-5. doi: 10.1007/s10072-020-04547-7

48. Rifino N, Censori B, Agazzi E, Alimonti D, Bonito V, Camera G, et al. Neurologic Manifestations in 1760 COVID-19 Patients Admitted to Papa Giovanni XXIII Hospital, Bergamo, Italy. J Neurol (2020) October:1-8. doi: 10.1007/s00415-020-10251-5

49. Chen T, Wu D, Chen H, Yan W, Yang D, Chen G, et al. Clinical Characteristics of 113 Deceased Patients With Coronavirus Disease 2019: Retrospective Study. BMJ (2020) 368:1-14. doi: 10.1136/bmj.m1091

50. Chuang DT, Aydemir S, Magda P, Thomas C, Zarnegar R. Neurological Manifestations as Primary Presentation of COVID-19 in Hospitalized Patients. Acta Neurol Scand (2021) 143(5):569-74. doi: 10.1111/ane.13399

51. Yeh EA, Collins A, Cohen ME, Duffner PK, Faden H. Detection of Coronavirus in the Central Nervous System of a Child With Acute Disseminated Encephalomyelitis. Pediatrics (2004) 113:e72-e6. doi: 10.1542/peds.113.1.e73

52. Turgay C, Emine T, Ozlem K, Muhammet SP, Haydar AT. A Rare Cause of Acute Flaccid Paralysis: Human Coronaviruses. J Pediatr Neurosci (2015) 10:280-1. doi: 10.4103/1817-1745.165716 
53. Sharma K, Tengsupakul S, Sanchez O, Phaltas R, Maertens P. Guillain-Barré Syndrome With Unilateral Peripheral Facial and Bulbar Palsy in a Child: A Case Report. SAGE Open Med Case Rep (2019) 7:1-5. doi: 10.1177/2050313X19838750

54. Yamana M, Kuwahara M, Fukumoto Y, Yoshikawa K, Takada K, Kusunoki S. Guillain-Barré Syndrome and Related Diseases After Influenza Virus Infection. Neurol: Neuroimmunol Neuroinflamm (2019) 6:1-7. doi: 10.1212/NXI. 0000000000000575

55. Berciano J, Orizaola P, Gallardo E, Pelayo-Negro AL, Sánchez-Juan P, Infante J, et al. Very Early Guillain-Barré Syndrome: A ClinicalElectrophysiological and Ultrasonographic Study. Clin Neurophysiol Pract (2020) 5:1-9. doi: 10.1016/j.cnp.2019.11.003

56. Jasti AK, Selmi C, Sarmiento-Monroy JC, Vega DA, Anaya JM, Gershwin ME. Guillain-Barré Syndrome: Causes, Immunopathogenic Mechanisms and Treatment. Expert Rev Clin Immunol (2016) 12:1175-89. doi: 10.1080/1744666X.2016.1193006

57. Gittermann LMT, Feris SNV. Giacoman AvO. Relation Between COVID-19 and Guillain-Barré Syndrome in Adults: A Systematic Review. Neurología (English Edition) (2020) 35:646-54. doi: 10.1016/j.nrleng.2020.07.005

58. Kim JE, Heo JH, Kim HO, Song SH, Park SS, Park TH, et al. Neurological Complications During Treatment of Middle East Respiratory Syndrome. J Clin Neurol (Korea) (2017) 13:227-33. doi: 10.3988/jcn.2017.13.3.227

59. Coen M, Jeansonc G, Almeidad LAC, Hübers A, Stierlin F, Najjar I, et al. Guillain-Barré Syndrome as a Complication of SARS-CoV-2 Infection. Brain Behavior Immun J (2020) 87:111-2. doi: 10.1016/j.bbi.2020.04.074

60. Camdessanche J-P, Morel J, Pozzetto B, Paul S, Tholance Y, Botelho-Nevers E. COVID-19 may Induce Guillain-Barré Syndrome. Rev Neurol (Paris) (2020) 176:516-20. doi: 10.1016/j.neurol.2020.04.003

61. Sedaghat Z, Karimi N. Guillain Barre Syndrome Associated With COVID-19 Infection: A Case Report. J Clin Neurosci (2020) 76:233-5. doi: 10.1016/ j.jocn.2020.04.062

62. Padroni M, Mastrangelo V, Asioli GM, Pavolucci L, Abu-Rumeileh S, Piscaglia MG, et al. Guillain-Barré Syndrome Following COVID-19: New Infection, Old Complication? J Neurol (2020) 267:1877-9. doi: 10.1007/ s00415-020-09849-6

63. Khalifa M, Zakaria F, Ragab Y, Saad A, Bamaga A, Emad Y, et al. GuillainBarré Syndrome Associated With Severe Acute Respiratory Syndrome Coronavirus 2 Detection and Coronavirus Disease 2019 in a Child. J Pediatr Infect Dis Soc (2020) 9:510-3. doi: 10.1093/jpids/piaa086

64. Alberti P, Beretta S, Piatti M, Karantzoulis A, Piatti ML, Santoro P, et al. GuillainBarré Syndrome Related to COVID-19 Infection. Neurol: Neuroimmunol Neuroinflamm (2020) 7(4):e741. doi: 10.1212/NXI.0000000000000741

65. Toscano G, Palmerini F, Ravaglia S, Ruiz L, Invernizzi P, Cuzzoni MG, et al. Vasoactive Intestinal Peptide in Checkpoint Inhibitor-Induced Pneumonitis. N Engl J Med (2020) 382:2573-4. doi: 10.1056/NEJMc2000343

66. Filosto M, Piccinelli SC, Gazzina S, Foresti C, Frigeni B, Servalli MC, et al. Guillain-Barré Syndrome and COVID-19: An Observational Multicentre Study From Two Italian Hotspot Regions. J Neurol Neurosurg Psychiatry (2020) 324837. doi: 10.1136/jnnp-2020-324837

67. Dufour C, Co T-K, Liu A. Gm1 Ganglioside Antibody and COVID-19 Related Guillain Barre Syndrome-a Case Report, Systemic Review and Implication for Vaccine Development. Brain behavior Immunity Health (2021) 12:100203. doi: 10.1016/j.bbih.2021.100203

68. Tekin AB, Zanapalioglu U, Gulmez S, Akarsu I, Yassa M, Tug N. Guillain Barre Syndrome Following Delivery in a Pregnant Woman Infected With SARS-Cov-2. J Clin Neurosci (2021) 86:190-2. doi: 10.1016/j.jocn.2021.01.028

69. Raahimi MM, Kane A, Moore CE, Alareed AW. Late Onset of Guillain-Barré Syndrome Following SARS-CoV-2 Infection: Part of 'Long COVID-19 Syndrome'? BMJ Case Rep CP (2021) 14(1):e240178. doi: 10.1136/bcr-2020-240178

70. Zhao H, Shen D, Zhou H, Liu J, Chen S. Guillain-Barré Syndrome Associated With SARS-CoV-2 Infection: Causality or Coincidence? Lancet Neurol (2020) 19:383-4. doi: 10.1016/S1474-4422(20)30109-5

71. Ottaviani D, Boso F, Tranquillini E, Gapeni I, Pedrotti G, Cozzio S, et al. Early Guillain-Barré Syndrome in Coronavirus Disease 2019 (COVID-19): A Case Report From an Italian COVID-Hospital. Neurol Sci (2020) 41:13514. doi: 10.1007/s10072-020-04449-8

72. Bastug A, Bektas H, Buyuktarakci C, Bodur H. Parainfectious Guillain Barre Syndrome in a Patient Diagnosed With COVID-19. Res Square (2021). doi: 10.21203/rs.3.rs-215097/v1
73. Khalifa M, Zakaria F, Ragab Y, Saad A, Bamaga A, Emad Y, et al. GuillainBarré Syndrome Associated With Severe Acute Respiratory Syndrome Coronavirus 2 Detection and Coronavirus Disease 2019 in a Child. J Pediatr Infect Dis Soc (2020) 9(4):510-3. doi: 10.1093/jpids/piaa086

74. Mancera-Páez O, Román GC, Pardo-Turriago R, Rodríguez Y, Anaya JM. Concurrent Guillain-Barré Syndrome, Transverse Myelitis and Encephalitis Post-Zika: A Case Report and Review of the Pathogenic Role of Multiple Arboviral Immunity. J Neurol Sci (2018) 395:47-53. doi: 10.1016/j.jns.2018.09.028

75. Hussain FS, Eldeeb MA, Blackmore D, Siddiqi ZA. Guillian Barré Syndrome and COVID-19: Possible Role of the Cytokine Storm. Autoimmun Rev (2020) 19(12):102681. doi: 10.1016/j.autrev.2020.102681

76. Willison HJ, Jacobs BC, van Doorn PA. Guillain-Barré Syndrome. Lancet (2016) 388:717-27. doi: 10.1016/S0140-6736(16)00339-1

77. Ang CW, Jacobs BC, Brandenburg AH, Laman JD, Van Der Meché FGA, Osterhaus ADME, et al. Cross-Reactive Antibodies Against GM2 and CMVinfected Fibroblasts in Guillain-Barre Syndrome. Neurology (2000) 54:14538. doi: 10.1212/WNL.54.7.1453

78. Rodríguez Y, Rojas M, Pacheco Y, Acosta-Ampudia Y, Ramírez-Santana C, Monsalve DM, et al. Guillain-Barré Syndrome, Transverse Myelitis and Infectious Diseases. Cell Mol Immunol (2018) 15:547-62. doi: 10.1038/ cmi.2017.142

79. Islam B, Islam Z, Geurtsvankessel CH, Jahan I, Endtz HP, Mohammad QD, et al. Guillain-Barré Syndrome Following Varicella-Zoster Virus Infection. Eur J Clin Microbiol Infect Dis (2018) 37:511-8. doi: 10.1007/s10096-018-3199-5

80. Goodfellow JA, Willison HJ. Guillain-Barré Syndrome: A Century of Progress. Nat Rev Neurol (2016) 12:723-31. doi: 10.1038/nrneurol.2016.172

81. Kim SY, Choe KW, Park S, Yoon D, Ock CY, Hong SW, et al. Mild Form of Guillain-Barré Syndrome in a Patient With Primary Epstein-Barr Virus Infection. Korean J Intern Med (2016) 31:1191-3. doi: 10.3904/kjim.2015.033

82. Jacobs BC, Rothbarth PH, FGAvd M, Herbrink P, Schmitz PIM, Klerk M, et al. The Spectrum of Antecedent Infections in Guillain-Barré Syndrome. Neurology (1998) 51:1110-5. doi: 10.1212/WNL.51.4.1110

83. Chroni E, Thomopoulos C, Papapetropoulos S, Paschalis C, Karatza CL. A Case of Relapsing Guillain-Barre Syndrome Associated With Exacerbation of Chronic Hepatitis B Virus Hepatitis. J Neurovirol (2003) 9:408-10. doi: 10.1080/13550280390201731

84. Ray G, Ghosh B, Bhattacharyya R. Acute Hepatitis B Presenting as GuillainBarré Syndrome. Indian J Gastroenterol (2003) 22:228-30.

85. Yimam KK, Merriman RB, Frederick RT. A Rare Case of Acute Hepatitis B Virus Infection Causing Guillain-Barré Syndrome. Gastroenterol Hepatol (2013) 9:121-3.

86. Sonavane AD, Saigal S, Kathuria A, Choudhary NS, Saraf N. Guillain-Barré Syndrome: Rare Extra-Intestinal Manifestation of Hepatitis B. Clin J Gastroenterol (2018) 11:312-4. doi: 10.1007/s12328-018-0847-3

87. Mardani M, Khodashahi R, Faghani Y. Guillain-Barre Syndrome Associated With Acute Hepatitis A: A Case Report. Asian J Case Rep Med Health (2020) 3:21-5.

88. Sivadon-Tardy V, Orlikowski D, Porcher R, Sharshar T, Durand MC, Enouf $\mathrm{V}$, et al. Guillain-Barré Syndrome and Influenza Virus Infection. Clin Infect Dis (2009) 48:48-56. doi: 10.1086/594124

89. Steininger C, Seiser A, Gueler N, Puchhammer-Stöckl E, Aberle SW, Stanek G, et al. Primary Cytomegalovirus Infection in Patients With Guillain-Barre Syndrome. J Neuroimmunol (2007) 183:214-9. doi: 10.1016/j.jneuroim.2006.11.006

90. Kennedy M, Apostolova M. A Rare Case of Infectious Mononucleosis Complicated by Guillain-Barre Syndrome. Neurol Int (2013) 5:20-2. doi: 10.4081/ni.2013.e7

91. Van Den Berg B, Walgaard C, Drenthen J, Fokke C, Jacobs BC, Van Doorn PA. Guillain-Barré Syndrome: Pathogenesis, Diagnosis, Treatment and Prognosis. Nat Rev Neurol (2014) 10:469-82. doi: 10.1038/nrneurol.2014.121

92. Loshaj-Shala A, Regazzoni L, Daci A, Orioli M, Brezovska K, Panovska AP, et al. Guillain Barré Syndrome (GBS): New Insights in the Molecular Mimicry Between C. Jejuni and Human Peripheral Nerve (HPN) Proteins. J Neuroimmunol (2015) 289:168-76. doi: 10.1016/j.jneuroim.2015.11.005

93. Yuki N. Infectious Origins of, and Molecular Mimicry in Guillain-Barré and Fisher Syndromes. Lancet Infect Dis (2001) 1:29-37. doi: 10.1016/S14733099(01)00019-6

94. Susuki K, Rasband MN, Tohyama K, Koibuchi K, Okamoto S, Funakoshi K, et al. Anti-GM1 Antibodies Cause Complement-Mediated Disruption of 
Sodium Channel Clusters in Peripheral Motor Nerve Fibers. J Neurosci (2007) 27:3956-67. doi: 10.1523/JNEUROSCI.4401-06.2007

95. Irie S, Saito T, Nakamura K, Kanazawa N, Ogino M, Nukazawa T, et al. Association of anti-GM2 Antibodies in Guillain-Barre Syndrome With Acute Cytomegalovirus Infection. J Neuroimmunol (1996) 68:19-26. doi: 10.1016/0165-5728(96)00059-8

96. Jacobs BC, Van Doorn PA, Groeneveld JHM, Tio-Gillen AP, Van Der Meché FGA. Cytomegalovirus Infections and anti-GM2 Antibodies in Guillain-Barré Syndrome. J Neurol Neurosurg Psychiatry (1997) 62:641-3. doi: 10.1136/jnnp.62.6.641

97. Loly JP, Rikir E, Seivert M, Legros E, Defrance P, Belaiche J, et al. GuillainBarré Syndrome Following Hepatitis E. World J Gastroenterol (2009) 15:1645-7. doi: 10.3748/wjg.15.1645

98. Nascimento OJM, Da Silva IRF. Guillain-Barré Syndrome and Zika Virus Outbreaks. Curr Opin Neurol (2017) 30:500-7. doi: 10.1097/WCO. 0000000000000471

99. Brito Ferreira ML, Militão de Albuquerque M, de Brito CAA, de Oliveira França RF, Porto Moreira ÁJ, de Morais Machado MÍ, et al. Neurological Disease in Adults With Zika and Chikungunya Virus Infection in Northeast Brazil: A Prospective Observational Study. Lancet Neurol (2020) 19:826-39. doi: 10.1016/S1474-4422(20)30232-5

100. Smith DW, Mackenzie J. Zika Virus and Guillain-Barré Syndrome: Another Viral Cause to Add to the List. Lancet (2016) 387:1486-8. doi: 10.1016/ S0140-6736(16)00564-X

101. Walteros DM, Soares J, Styczynski AR, Abrams JY, Galindo-Buitrago JI, Acosta-Reyes J, et al. Long-Term Outcomes of Guillain-Barré Syndrome Possibly Associated With Zika Virus Infection. PloS One (2019) 14:1-14. doi: 10.1371/journal.pone.0220049

102. Stegmann-Planchard S, Gallian P, Tressières B, Leparc-Goffart I, Lannuzel A, Signaté A, et al. Chikungunya, a Risk Factor for Guillain-Barré Syndrome. Clin Infect Dis (2020) 70:1233-5. doi: 10.1093/cid/ciz625

103. Rosário M, Jesus P, Vasilakis N, Farias DS, Novaes MAC, Rodrigues SG, et al. Case Report: Guillain-barré Syndrome After Zika Virus Infection in Brazil. Am J Trop Med Hyg (2016) 95:1157-60. doi: 10.4269/ajtmh.16-0306

104. Cao-Lormeau VM, Blake A, Mons S, Lastère S, Roche C, Vanhomwegen J, et al. Guillain-Barré Syndrome Outbreak Associated With Zika Virus Infection in French Polynesia: A Case-Control Study. Lancet (2016) 387:1531-9. doi: 10.1016/S0140-6736(16)00562-6

105. Santos TD, Rodriguez A, Almiron M, Sanhueza A, Ramon P, Oliveira W, et al. Zika Virus and the Guillain-Barré Syndrome - Case Series From Seven Countries. New Engl J Med (2016) 375:1598-601. doi: 10.1056/ NEJMc1609015

106. Rivera-Correa J, De Siqueira IC, Mota S, Do Rosário MS, De Jesus PAP, Carlos LJr, et al. Anti-Ganglioside Antibodies in Patients With Zika Virus Infection-Associated Guillain-BarréSyndrome in Brazil. PloS Negl Trop Dis (2019) 13:1-13. doi: 10.1371/journal.pntd.0007695

107. Baskar D, Amalnath D, Mandal J, Dhodapkar R, Vanathi K. Antibodies to Zika Virus, Campylobacter Jejuni and Gangliosides in Guillain-Barre Syndrome: A Prospective Single-Center Study From Southern India. Neurol India (2018) 66:1324-31. doi: 10.4103/0028-3886.241402

108. Siu R, Bukhari W, Todd A, Gunn W, Huang QS, Timmings P. Acute Zika Inection With Concurrent Onset of Guillain-Barré Syndrome. Neurology (2016) 87:1623-4. doi: 10.1212/WNL.0000000000003038

109. Mancera-Páez O, Román GC, Pardo-Turriago R, Rodríguez Y, Anaya J-M. Concurrent Guillain-Barré Syndrome, Transverse Myelitis and Encephalitis Post-Zika: A Case Report and Review of the Pathogenic Role of Multiple Arboviral Immunity. J Neurol Sci (2018) 395:47-53. doi: 10.1016/j.jns. 2018.09.028

110. Munhoz RP, Pedroso JL, Nascimento FA, De Almeida SM, Barsottini OGP, Cardoso FEC, et al. Neurological Complications in Patients With SARSCoV-2 Infection: A Systematic Review. Arq Neuropsiquiatr (2020) 78:290300. doi: 10.1590/0004-282x20200051

111. Cappello F, Marino Gammazza A, Dieli F, Conway de Macario E, Macario AJ. Does SARS-CoV-2 Trigger Stress-Induced Autoimmunity by Molecular Mimicry? A Hypothesis J Clin Med (2020) 9:2038. doi: 10.3390/jcm9072038

112. Lucchese G, Kanduc D. Zika Virus and Autoimmunity: From Microcephaly to Guillain-Barré Syndrome, and Beyond. Autoimmun Rev (2016) 15:801-8. doi: 10.1016/j.autrev.2016.03.020
113. Lucchese G, Flöel A. Sars-CoV-2 and Guillain-Barré Syndrome: Molecular Mimicry With Human Heat Shock Proteins as Potential Pathogenic Mechanism. Cell Stress Chaperones (2020) 25:731-5. doi: 10.1007/s12192020-01145-6

114. Needham EJ, Chou SHY, Coles AJ, Menon DK. Neurological Implications of COVID-19 Infections. Neurocrit Care (2020) 32:667-71. doi: 10.1007/ s12028-020-00978-4

115. Moudgil KD, Thompson SJ, Geraci F, De Paepe B, Shoenfeld Y. Heat-Shock Proteins in Autoimmunity. Autoimmune Dis (2013) 2013:1-3. doi: 10.1155/ 2013/621417

116. Chiba S, Yokota SI, Yonekura K, Tanaka S, Furuyama H, Kubota H, et al. Autoantibodies Against HSP70 Family Proteins Were Detected in the Cerebrospinal Fluid From Patients With Multiple Sclerosis. J Neurol Sci (2006) 241:39-43. doi: 10.1016/j.jns.2005.10.009

117. Prabhakar S, Kurien E, Gupta RS, Zielinski S, Freedman MS. Heat Shock Protein Immunoreactivity in CSF Correlation With Oligoclonal Banding and Demyelinating Disease. Neurology (1994) 44(9):1644. doi: 10.1212/WNL. 44.9.1644

118. Romi F, Helgeland G, Gilhus NE. Heat-Shock Proteins in Clinical Neurology. Eur Neurol (2011) 66:65-9. doi: 10.1159/000329373

119. Helgeland G, Petzold A, Hoff JM, Gilhus NE, Plant GT, Romi FR. Anti-Heat Shock Protein 70 Antibody Levels are Increased in Myasthenia Gravis and Guillain-Barré Syndrome. J Neuroimmunol (2010) 225:180-3. doi: 10.1016/ j.jneuroim.2010.04.024

120. Yonekura K, Yokota SI, Tanaka S, Kubota H, Fujii N, Matsumoto H, et al. Prevalence of Anti-Heat Shock Protein Antibodies in Cerebrospinal Fluids of Patients With Guillain-Barré Syndrome. J Neuroimmunol (2004) 156:204-9. doi: 10.1016/j.jneuroim.2004.07.017

121. Hart IK, Kennedy PG. Guillain-Barré Syndrome Associated With Cytomegalovirus Infection. QJM (1988) 67:425-30. doi: 10.1093/ oxfordjournals.qjmed.a068208

122. Zhang H-L, Zheng X-Y, Zhu J. Th1/Th2/Th17/Treg Cytokines in GuillainBarré Syndrome and Experimental Autoimmune Neuritis. Cytokine Growth Factor Rev (2013) 24(5):443-53. doi: 10.1016/j.cytogfr.2013.05.005

123. Hohnoki K, Inoue A, Koh C-S. Elevated Serum Levels of IFN- $\gamma$, IL-4 and TNF- $\alpha /$ Unelevated Serum Levels of IL-10 in Patients With Demyelinating Diseases During the Acute Stage. J Neuroimmunol (1998) 87(1-2):27-32. doi: 10.1016/S0165-5728(98)00053-8

124. Li S, Yu M, Li H, Zhang H, Jiang Y. Il-17 and IL-22 in Cerebrospinal Fluid and Plasma are Elevated in Guillain-Barre Syndrome. Mediators Inflamm (2012) 2012:260473. doi: $10.1155 / 2012 / 260473$

125. Maddur MS, Rabin M, Hegde P, Bolgert F, Guy M, Vallat J-M, et al. Intravenous Immunoglobulin Exerts Reciprocal Regulation of Th1/Th17 Cells and Regulatory T Cells in Guillain-Barré Syndrome Patients. Immunol Res (2014) 60(2):320-9. doi: 10.1007/s12026-014-8580-6

126. Thepmankorn P, Bach J, Lasfar A, Zhao X, Souayah S, Chong ZZ, et al. Cytokine Storm Induced by SARS-CoV-2 Infection: The Spectrum of its Neurological Manifestations. Cytokine (2020) 138:155404. doi: 10.1016/ j.cyto.2020.155404

127. Garcia MA, Barreras PV, Lewis A, Pinilla G, Sokoll LJ, Kickler T, et al. Cerebrospinal Fluid in COVID-19 Neurological Complications: No Cytokine Storm or Neuroinflammation. medRxiv (2021). doi: 10.1101/ 2021.01.10.20249014

128. Jasti AK, Selmi C, Sarmiento-Monroy JC, Vega DA, Anaya J-M, Gershwin ME. Guillain-Barré Syndrome: Causes, Immunopathogenic Mechanisms and Treatment. Expert Rev Clin Immunol (2016) 12(11):1175-89. doi: 10.1080/ 1744666X.2016.1193006

Conflict of Interest: The authors declare that the research was conducted in the absence of any commercial or financial relationships that could be construed as a potential conflict of interest.

Copyright $\odot 2021$ Shoraka, Ferreira, Mohebbi and Ghaemi. This is an open-access article distributed under the terms of the Creative Commons Attribution License (CC BY). The use, distribution or reproduction in other forums is permitted, provided the original author(s) and the copyright owner(s) are credited and that the original publication in this journal is cited, in accordance with accepted academic practice. No use, distribution or reproduction is permitted which does not comply with these terms. 